\title{
IMPACT OF CLINICAL DEPRESSION ON ACADEMIC PERFORMANCE OF STUDENTS AT UNIVERSITY OF KARACHI
}

\author{
Rizwana Faseel Hussain \\ Associate professor, \\ Department of Education, University of Karachi, \\ Sindh, Pakistan \\ Email: rizwana.faseel@uok.edu.pk

\section{Baber Khan} \\ Teaching Associate, \\ Department of Education, University of Karachi, \\ Sindh, Pakistan \\ Email: k.babar@hotmail.com

\section{Syed Ahsan Ali Shah} \\ Research Scholar, \\ Department of Education, University of Karachi, \\ Sindh, Pakistan \\ Email: delc.disc@gmail.com
}

\begin{abstract}
The aim of this research study is to find out cause and effect of clinical depression on academic achievements and performance of students. The Main objective of this chronic mental illness is to find out the striking depth of stress and depression on learning outcomes of students. Factors that impact on academic performance caused by clinical depression were investigated. Literature review indicates that clinical depression negatively impact on academic performance of students in terms of lack of confidence, communication problem, time management and trust issues particularly at university level. Public sector university of Karachi was selected as the population of the study. This research is based on the quantitative method. Questionnaire has been set, as a tool for this research. The sample size included 100 students from twenty departments of eight faculties through simple random sampling. Data analysis has been done by descriptive statistical techniques using percentage method. Closed ended questionnaire tool were designed for the collection of data based on five liker scale. The collected was analyzed and results were at moderate level $33 \%$ respondents were strongly agree, $47 \%$ agree, $13 \%$ neutral while strongly disagree and disagree were $7 \%$.The findings of this research shows that clinical depression adversely impact on academic performance of the students at University of Karachi. It affects academic
\end{abstract}


performance as well as it has long term impact on student's mental performance. The hypothesis considered for this research is accepted.

\section{KEYWORDS}

Depression, Clinical Depression, Academic Performance, University Students

\section{INTRODUCTION}

This millennium is supposed to be the era of competition and acceleration in their fields no matters by hooks or by crooks. In this speedy and versatile climate it is difficult to keep itself fit and healthy either physically or mentally. Life is not a bed of roses it is rough and tough where failure is an option but giving up not. Nature has created every human with certain strength of sentiments and emotions which we use to cope up it in crust and trough of competent life. On the other hand if someone fails to face the hardships and ignorance so, Depressions and stress plough a field of failures. Which distract the student from their academic strength and productivity and ultimately fallen in the ditch of sorrow and anxiety.

Depression and stress is often ignored illness knowingly and unknowingly. It is supposed to be common human act. Boyce, J., Rotenberg, C., \& Karam, M. (2015). Clinical depression is defined as a mood disorder caused by many factors, including genetic predisposition, personality, stress, and brain chemistry. Clinical stress and depression has destructive effects on personal traits such as lack of interest, creativity, and social circle. Unpredictable behavior is often a sign of anxiety or depression (Canadian Centre for Justice Statistics, 2012)

Student's life is a collage of emotions and dreams no matter these are realistic or imaginary. They try their level best to acquire in the scorching heat of struggle and nerves getting efforts but when they find it all in vain so dead end of clinical depression halt the accumulated energy and dare. This dead end intoxicates the student's academic performance and causes the brain drain of emerging talent either in bad activities or intoxication.

Academic life is a garden of dreams and hopes where we knit aims and objectives in the canvas of future and put the shoulders to the wheel in order to achieve to make track record of success but distant drums sounds well and everyone is not lucky enough to acquire the desired goals. Learning period of time is supposed to be a golden era of whole life which leaves deep remarks in our personality and life whether positive or negative. Motivation is the best pills to reduce the stress and depression in academic life of every student. It enables us to drain out the depression and rejuvenate our spirits and hopes. 
Academic activity is blessed by clinical depression on the other hand it reflects reversely bad in physical performance. It becomes the cause of resistance in the path of achievements and bright virtue of behavior while sweeping their faults and errors under the carpet. Numbers of cases of stress and anxiety are increasing annually consecutively mostly effected age group is between 8 to 15 years. 1 out of 8 children has anxiety, Evans, T. M., Bira, L., \& Vanderford, N. L. (2019). Reply to 'A lack of evidence for six times more anxiety and depression in US graduate students than in the general population'.

\section{LITERATURE REVIEW}

Clinical depression puts a hamper to destruct the person's behavior in all means especially academic performance. Depression is supposed to be a nightmare in the dreamland of academic success and achievements. It leaves no sign of hope to rise after falling in the track of educational process. This research will reveal the effect of clinical depression on academic performance at University of Karachi. In the current era everyone believes that knowledge opens the door of success. The whole academic life is the training of sharpening the skills and knowledge not to secure the degree. This careful research study is vital and important to highlight the root cause and their impact to grow clinical depression as an ulcer in the academic achievements of student's career and behavior.

Mental uncertainty is a common issue of all and sundry for every age of people. Pakistan is a country where people never feel itself stable in any part of life just because of lack of guidance and counseling from every angle of moral support by friend and family. Ignorance is a blessing in our society because we use our will power not to accept and beat the illness but to hide and turn a blind eye from consequences. This study will help the students to evaluate itself after every failure either we are strengthening ourselves or falling a prey of depression. It is a routine observation that to hide illness is to suffer illness. Self-evaluation is the best laboratory to nip this evil mental illness in the bud.

Depression is supposed to be normally exist disorder which lies in different shapes and frames of behavior, broadening on normality, to critical (psychotic) state which consists of hallucinations and delusions. Globally it strikes the normal activities to abnormality and prime root cause of premature death. "Depression is the most common, mental illness and is said to be a leading cause of dis-functioning and disability worldwide". Iasevoli, F., Giordano, S., Balletta, R., Latte, G., Formato, M. V., Prinzivalli, E., \& de Bartolomeis, A. (2016). Treatment resistant schizophrenia is associated with the worst community functioning among severely-ill highly-disabling psychiatric conditions and is the most relevant predictor of poorer achievements in functional milestones. Progress in Neuro-Psychopharmacology and Biological 
Psychiatry, 65, 34-48.

At university level learners encounter various strange and peculiar hurdles in contrast to other learning periods.Many young people face many refutations and responsibilities to succeed $^{5}$. University students also have to deal with the new experiences and changes in social aspects, and in behavioral, emotional, academic and economic situation. Oginni, O. A., Mosaku, K. S., Mapayi, B. M., Akinsulore, A., \& Afolabi, T. O. (2018). Depression and associated factors among gay and heterosexual male university students in Nigeria. Archives of sexual behavior. The mental health problems are commonly seen at different levels of education, such as college and university. Ediz, B., Ozcakir, A., \& Bilgel, N. (2017). Depression and anxiety among medical students: Examining scores of the beck depression and anxiety inventory and the depression anxiety and stress scale with student characteristics.

The study done by Larson et.al explored both physical and mental health issues. This study found that mental health issues were significantly and negatively associated with GPA. The results of the study also showed that physical health issues were often correlated with mental health issues. Larson, M., Orr, M., \& Warne, D. (2016). Using student health data to understand and promote academic success in higher education settings. Sometime depression becomes critical if it is not taken serious and mental illness. Stress and depression causes not only performance downfall of individuals but also the curse for the closed ones because in some exceptional cases student feels pleasures and satisfaction to harm and let down others especially bench fellows. In this state of mind students do not compete the opponent by hard working however put a hamper in their academic achievements and tries to super cede from them by evil means.

\section{RESEARCH OBJECTIVES}

1. To investigate the factors which develop clinical depression on students at university level.

2. To show how these factors affects students' academic performance.

3. Challenges faced by teachers in recognition depression or anxiety in students.

4. To enable the student avoid depression and combat rest of life.

\section{RESEARCH HYPOTHESES}

1. Clinical depression has a significant impact on academic performance of the students at University of Karachi.

2. Through adoption of remedial techniques clinical depression can be reduced and at certain level it can be eliminated.

3. Clinical depression of different genders (Female and male) has different impact on student's academic performance. 


\section{RESEARCH METHODOLOGY}

A survey was chosen to practice this research. The population of the study was University of Karachi in which 8 Faculties were selected. It includes Faculty of Social Sciences, Faculty of Education, Faculty of Islamic Studies, Faculty of Law, Faculty of Pharmacy \& Pharmaceutical Sciences, Faculty of Management \& Administrative Sciences, Faculty of Engineering and Faculty of Science

The sampling type is random sampling because it is the requirement of the study to collect data which shows the impact of clinical depression on academic performance of students at University of Karachi. Total 20 departments were selected from 8 faculties. 5 students of each department were asked to fill the questionnaire. The overall sampling size is 100. The research instrumentfor this study is Questionnaire. A questionnaire is designed comprising of 20 items. Data were collected through visits from selected 20 departments.

\section{RESEARCH FINDINGS}

Item 1: Clinical depression of different genders (Female and male) has different impact on student's academic performance.

Table 1

Gender

\begin{tabular}{ccc}
\hline Responses From & Frequency & Percentage \\
\hline Female & 63 & $63 \%$ \\
Male & 37 & $37 \%$ \\
Total & 100 & $100 \%$ \\
\hline
\end{tabular}

Item 2: Clinical depression has negative effects on behaviors which impacts on academic performance.

Table 2

Impact of clinical depression on academic performances

\begin{tabular}{ccc}
\hline Responses & Frequency & Percentage \\
\hline Strongly Agree & 42 & $42 \%$ \\
Agree & 45 & $45 \%$ \\
Neutral & 12 & $12 \%$ \\
Dis Agree & 1 & $1 \%$ \\
Strongly Disagree & 0 & $0 \%$ \\
Total & 100 & $100 \%$
\end{tabular}

Item 3: Through adoption of remedial techniques clinical depression can be reduced.

Table 3

Role of adoption of remedial techniques

\begin{tabular}{ccc}
\hline Responses & Frequency & Percentage \\
\hline \hline
\end{tabular}




\begin{tabular}{ccc}
\hline Strongly Agree & 23 & $23 \%$ \\
Agree & 48 & $48 \%$ \\
Neutral & 26 & $26 \%$ \\
Dis Agree & 2 & $2 \%$ \\
Strongly Disagree & 1 & $1 \%$ \\
Total & 100 & $100 \%$ \\
\hline
\end{tabular}

Item 4: What are the challenges faced by students while going through Depression?

Table 4

Challenges faced by students while going through depression

\begin{tabular}{|c|c|}
\hline Challenges & Percentage \\
\hline Communication. & $19 \%$ \\
\hline Unable to focus on studies. & $10 \%$ \\
\hline Time management issues. & $16 \%$ \\
\hline Memory issues. & $4 \%$ \\
\hline Emotions. & $10 \%$ \\
\hline Trust issues. & $17 \%$ \\
\hline Relationship issues. & $10 \%$ \\
\hline Health issues. & $7 \%$ \\
\hline Mood swings. & $7 \%$ \\
\hline Total & $100 \%$ \\
\hline
\end{tabular}

Item 5: During depression students lost their confidence of discussion during lectures.

Table 5

Losing the confidence of discussion while going through depression

\begin{tabular}{ccc}
\hline Responses & Frequency & Percentage \\
\hline Strongly Agree & 28 & $28 \%$ \\
Agree & 48 & $48 \%$ \\
Neutral & 16 & $16 \%$ \\
Dis Agree & 7 & $7 \%$ \\
Strongly Disagree & 1 & $1 \%$ \\
Total & 100 & $100 \%$ \\
\hline
\end{tabular}

\section{CONCLUSION AND DISCUSSION}

This research shows that there were total 100 respondents, participated in the survey. $37 \%$ of the respondents were males and $63 \%$ of the respondents were females. Majority of the respondents were females. Females are supposed to be more sensitive than males due to which the ratio of depression in females is observed higher than males. Furthermore females are major part of world population. The finding of this study 
proves that Clinical depression of different genders (Female and male) has multiple impacts on student's academic performance.

This study shows that Clinical depression has significant negative effects on behaviors which impact academic performance. Keeping in view the statistics and designed tool responses it is most evidently seen that depression and stress leaves long lasting destructive imbalances in behavior and academic output. The factors that causes clinical depression includes exam pressure, inferiority complex, personal issues, burden of study, financial issues, response of teachers which also includes favoritism and gender discrimination, fear of refusal, unexpected outcomes and CGPA, presentation and report submissions burden. Besides this it is also affected by isolation, dejection from society and imaginary planning from their grounds. However, through this research it also reveals that through adoption of remedial techniques clinical depression can be alleviated and at certain level it can be cured timely. Remedial techniques include proper sittings and visits in terms of treatment, counseling and peer support. Communication problem, time management and trust lapses are the most common challenge faced by students while going through depression. Furthermore, it is also revealed that majority of the depressed students lost their confidence of discussion during lecture.

Research study also explores that clinical depression is not an inherited problem which is transferred from generation to generation it could be an accidental incident which swallow gradually in brain and take control of whole nervous system and slow down the performance of every plan and decision. Everything seems near around but difficult to catch. Academic achievements drop and fall like leaves in autumn ultimately courage and dare got weak enough to lose all traits of behavior and track records.

Survey also classify that females are most affected gender which is supposed to be an ideal state to investigate stress and depression. Nature has created female as a sentimental in every act of life and male stone hearted. It has been observed that females easily suffer in this mental illness of stress and depression and lost it identity and feel pleasure to dissolve its personality and set a mind to live in this lost world. On the contrary some of them gain negative energy from depression and harm other to let down in their academic downfall it gives them temporary pleasure and satisfaction.

Remedial techniques on time can play vital role to abstain other and itself from wrath of this negative energy. Although it is a long and time taking process but success ratio is maximum if guide and counselor is well skilled and experienced. It has been revealed that confidence is a highly affected trait of behavior in academic performance which is easily vaporized with in no time and need multiple remedial techniques to develop in personality again. This is the last building stone of personality which plays a significant 
role in academic achievements.

\section{RECOMMENDATIONS}

1. Students should be engaged in different modes of advisory sessions, counseling and guidance workshops or mental strengthening programs.

2. Physical and mental exercises like meditation and competitive task must be organized to keep them busy.

3. Students should be allowed to drain out their stress with their friends and family or loved ones like friends or teachers.

4. Students guide and counselor must great observer and highly skilled.

5. University should provide counselor to each department.

6. Motivational stuff in the forms of stories or movies should be a part of cocurricular activities.

7. Periodic check and balance chart should be maintained to keep the student on track.

8. Loneliness must be weeded out from the surroundings of students.

9. Friend and family must give moral support to stand it own bottom.

10. The teachers need to be competent enough to keep a close eye on highly depressed students, because academic performance can be judged and rectify with in classroom activity.

\section{REFERENCES}

Abouserie, R. (1994). Sources and levels of stress in relation to locus of control and self-esteem in university students. Educational psychology, 14(3), 323-330.

Andrews, B., \& Wilding, J. M. (2004). The relation of depression and anxiety to life-stress and achievement in students. British journal of psychology, 95(4), 509-521.

Arslan, G., Ayranci, U., Unsal, A., \& Arslantas, D. (2009). Prevalence of depression, its correlates among students, and its effect on health-related quality of life in a Turkish university. Upsala journal of medical sciences, 114(3), 170-177.

Bayram, N., \& Bilgel, N. (2008). The prevalence and socio-demographic correlations of depression, anxiety and stress among a group of university students. Social psychiatry and psychiatric epidemiology, 43(8), 667-672.

Beiter, R., Nash, R., McCrady, M., Rhoades, D., Linscomb, M., Clarahan, M., \& Sammut, S. (2015). The prevalence and correlates of depression, anxiety, and stress in a sample of college students. Journal of affective disorders, 173, 90-96.

Cai, S. (2000). Physical exercise and mental health: A content integrated approach in coping with college sudents' anxiety and depression. Physical Educator, 57(2), 69.

Cassady, J. C., Pierson, E. E., \& Starling, J. M. (2019, February). Predicting student depression with measures of general and academic anxieties. In Frontiers in Education (Vol. 4, p. 11). Frontiers.

Ginwright, S., \& James, T. (2002). From assets to agents of change: Social justice, organizing, and youth development. New directions for youth development, 2002(96), 27-46. 
Interian, A., Martinez, I., Rios, L. I., Krejci, J., \& Guarnaccia, P. J. (2010). Adaptation of a motivational interviewing intervention to improve antidepressant adherence among Latinos. Cultural Diversity and Ethnic Minority Psychology, 16(2), 215.

Larson, M., Orr, M., \& Warne, D. (2016). Using student health data to understand and promote academic success in higher education settings. College student journal, 50(4), 590-602.

Lepp, A., Barkley, J. E., \& Karpinski, A. C. (2014). The relationship between cell phone use, academic performance, anxiety, \& satisfaction with life in college students. Computers in human behavior, 31, 343-350.

Lyubomirsky, S., Caldwell, N. D., \& Nolen-Hoeksema, S. (1998). Effects of ruminative and distracting responses to depressed mood on retrieval of autobiographical memories. Journal of personality and social psychology, 75(1), 166.

M. D., Heinz, M., Huang, R., \& Jacobson, N. C. (2020). Predictive Modeling of Psychiatric Illness using Electronic Health Records and a Novel Machine Learning Approach with Artificial Intelligence.

O'Neil, M. K., \& Mingie, P. (1988). Life stress and depression in university students: Clinical illustrations of recent research. Journal of American College Health, 36(4), 235-240.

Poole, N., \& Greaves, L. (2012). Becoming trauma informed. Toronto, Canada: Centre for Addiction and Mental Health.Nemesure.

Stress, A. A. D. A. (2017). Anxiety and Depression Association of America. Retrieved October, 20. 